\title{
Human Resource Management of Teachers at Madrasah Aliyah Pesantren:An Education Quality Perspective
}

\author{
Baso $^{1}$, Muhammad Rusdi Rasyid ${ }^{2}$, Sain Hanafy ${ }^{3}$ \\ ${ }^{*}$ Sekolah Tinggi Agama Islam (STAI) Al-Furqan Makassar, Indonesia \\ e-mail: andiasoparakkasi@gmail.com \\ ${ }^{2}$ Sekolah Tinggi Agama Islam Negeri (STAIN) Sorong, Papua, Indonesia \\ e-mail: rusdipasca@gmail.com \\ ${ }^{3}$ Universitas Islam Negeri (UIN) Alauddin, Makassar, Indonesia \\ e-mail: sainha503@gmail.com
}

\begin{abstract}
This paper discusses human resource management from an education quality perspective. This study aims to find out the description of human resources in building the quality of education. This study applies descriptive qualitative. Data source from Madrasah principals, heads of administration, head of curriculum and evaluation, and educators. Data collection method by interviewing the participants. The instrument of this study uses interview guidelines. Data analysis were carried out through three stages, namely data reduction, data presentation, and conclusion. The results showed that human resources in the Madrasah Aliyah IMMIM Makassar Modern Islamic Boarding School were in the good category. The reality of the quality of education shows very satisfying results, it is categorizedin very good. The implication of this study is that it is hoped that it can become information and reference about the need to review the activities of human resource management in developing the quality of education, primarily from the perspective of internal customers consisting of educators and education personnel as "motor" all activities of madrasah and not just factors of production but also assets that need attention. The reality of the implementation of human resource management in several schools and madrasah needs to be evaluated more intensively to find out more about the potential advantages and disadvantages and limitations of each school or madrasah.
\end{abstract}

\section{Keywords-Management; human resource; education quality}

\section{INTRODUCTION}

The existence and socioeconomic status many judges a person's success in the era of globalization, someone called success is often only measured by material calculations and worldly wealth, even though in the eyes of God may be concerned are considered fooled by the glamor of the world. Radical changes and discontinuities characterize the development of the work and business environment. The paradigm shifts from the industrial era to the information technology era. Information technology applications require the ability of organizations to develop and transfer knowledge that is indispensable in organizational development[1].

In this condition, the products and services produced by the organization are distinguished by knowledge and intellectual models that are only 
possessed by human resources (HR). Therefore, the role of competent human resources is needed, namely human resources who have knowledge (knowledge-based workers) and have the skills so that they can adapt to changes in the environment, making education as a vehicle for the development of human resources (HR), both education that takes place in the family, school or madrasa, and community. This phenomenon consents to innovative challenges and opportunities for organizations to be able to understand and create useful organizational management concepts through the management or management of Human Resources (HR). HR management is recognized as a global and integral issue of international competitiveness. It cannot be denied that all problems that arise are from humans and can only be solved and managed by humans[2].

It is interesting here, in times of rapid and complex changes in the world of work and business environments such as demography, geography, type of business, environment and the impact of globalization, it requires organizations to adapt and be proactive quickly with the environment. That is, HR management must be able to anticipate various developments that are and will occur, then take various actions to answer these challenges, which in turn can create competitive advantages that other organizations do not have.

The existence of demands like this is a necessity for HR management to change the existing functions in HR management, oriented to the "result." Changes in the role of the responsive management system work proactively, and the functional structure to a more flexible structure and implement strategic policies. This is the responsibility of the HR management, given that proper management of management will lead to the success of an organization. In this organizational change framework, it is necessary to manage the appropriate HR Management so that the organization can be managed more professionally. This change in paradigm will be beneficial for the organization if it is feasiblefor that organization. In this case, leadership commitment is an absolute matter, because the leader has the most significant responsibility for the overall success of the organization[3].

Correspondingly, for the world of education, the support of strong HR management to achieve competitive advantage and quality improvement is necessary. This is because education is a strategic media to improve the quality of human resources and the quality of a nation. Therefore, it is expectedthat many countries give development priorities in the education sector, and make education as a parameter of competitiveness and progress of the nation. The progress of several nations around the world is inseparable from the progress that began in the field of education. The Indonesian people also believed the statement. However, the reality of Indonesia's education system has not shown the expected quality and success. National education has not been able to create superior human resources, both regarding intellectuality, morality, spirituality, professionalism, and competitiveness or national competition.

The managers of Islamic educational institutions in the country dealing with a complicated situation. Generally, Islamic education institutions have low accreditation scores. There are still many Islamic education institutions that have not been managed professionally and only become a land to earn a 
living for a particular family or group; become a shelter for scholars who have not had a permanent job, and it becomes a land for the part-time job. As a result, most Islamic educational institutions in this country are still struggling, living reluctantly to die not want to, so that it is difficult to distinguish whether these institutions exist or do not exist[4].

In addition to the above problems, another problem in Islamic educational institutions in general and closely related to the problem of HR Managementis a recruitment process which is only a shift of the position of the old people who have "meritorious."Prospective educators or educators feel that they only get an offer to work. They feel invited to talk frequently and eventually asked to work, then how do the school know the prospective workforce has met the required specifications [5].

This condition is exacerbated by the apologetic attitude of some managers of Islamic education institutions. Many of them consider the underdevelopment of Islamic education institutions as something that is natural and unnecessary to worry about because it has happened since the colonial era. "Lack of funds," lack of facilities," and" under-assistance "are the daily gossip of managers of Islamic education institutions when they receive criticism. Very few of them can say that the leading cause of all forms of underdevelopment is low performance and quality management [4].

As an agent of change in social change, Islamic education in the atmosphere of modernization and globalization is now required to be able to play its role dynamically proactively. The presence of madrasah as one of the representations of Islamic education institutions is expected to be able to bring about significant changes and contributions to the improvement of the position of Muslims, both on the plains of the human resources intellectually, morally, spiritually and on a practical plane in the form of solutions to the problems of the people. For madrasah that are managed with professional management, they will grow healthy and active, so they can continue to improvise, develop credible and marketable programs. In turn, it becomes the leading programs of the community. In contrast, madrasahwhich is in bad management could gradually be left behind by the community. In the not too distant future, educational institutions like this will die, stop and die[6].

It seems that Islamic education institutions, especially madrasah are insufficientto take various managerial actions and activities. Managerial activities are required to be able to realize improving the quality of institutions, such as how madrasah management seeks to improve the worklife satisfaction of personnel.This is important, given that not a few educational institutions, including Islamic education institutions that only think about how to produce good educational output, but less attention to how to provide job satisfaction to personnel - which is the "driving force" of education in schools - in life it works. Alternatively, make the success parameters of the leader not located in the suitability between the implementation of the program and the planning. However, more on how big 
the leader can benefit his organization so that professionalism is no longer needed. Educational institutions are only an arena for power and influence[7].

The existence of a madrasa does not merely show the characteristics of Islam but can realize the desired and believed goals as the most ideal[6]. The aim is at the same time to emphasize that the mission and responsibility carried out by Islamic education institutions/madrasah are even harder, namely to prepare quality output and have reliable Human Resources (HR). Related to this God said in QS al-Nisa / 4: 9 [8] as follows:

The translation: And be afraid of those who, leave behind those who are weak, who they are concerned. Therefore let them fear Allah and let them say the right words.

The verse implies that Islamic education institutions/madrasa are required to produce strong graduates, namely graduates who have distinguished personalities, noble character and have knowledge and master technology. The condition of Islamic education institutions (madrasah) is currently becoming an objective reality that occurs in almost all madrassas in Indonesia, both public and private madrasah. Although the adequacy of facilities and facilities slightly more benefits state madrasah, in general, they deal with quite complex problems especially about the independence of institutions to develop institutional visions. The competitiveness of state madrasah is not enough to speak much in the context of improving quality and the tight competition in the education world.This study provides an overview and comparison as a strategic material in the management of human resource management and suggests an effort to reconstruct managerial weaknesses in madrasah. Also, it is expected that the madrasah as an Islamic education institution could later become a center of excellencein the form of professional management.

\section{LITERATURE REVIEW}

\section{A. Definition of Human Resource Management}

The term Human Resources is a series of words that contain a unified understanding. The series of words can be separated into two groups consisting of the words "Management" and "Human Resources."The term of management contains broad meaning. Management involvessystem, process, function, science, group of people, a separate activity, and profession[9].George R. Terry [10]provides a management definition as a distinct process consisting of planning, organizing, actuating and controlling, performed to determine and accomplished stated objectives by the use of human being and other resources.KontzandO'Donnel[11] revealed that management is an effort to achieve specific goals through the activities of others; thus the manager coordinates some other people's activities which include planning, organizing, placing, mobilizing and controlling.Andrew F. Sikula[12]defines general management as referring to planning, organizing, controlling, staffing, leading, motivating, communicating, and decision making. The organization performsactivities to coordinate the varied resources of the enterprise to bring an efficient creation of some product or 
service.OemarHamalik[13]states an operational formula that might be proposed, that management is a social process that deals with the overall human endeavor and other sources of resources using efficient and effective methods to achieve predetermined goals.James A. F. Stoner[14] states management is the process of planning, organizing, leading and controlling various efforts of members of the organization and the process of using all organizational resources in order to achieve organizational goals.

Management is a process, in the sense that activities in management include several stages of chain activities carried out continuously in order to achieve the stated goals.In the management, there are knownessential functions, and the simplest consists of four types of functions, namely: planning, organizing, actuating and controlling. It is said to be simple because some scholars formulate several management functions by their respective backgrounds, views or orientations which in principle can be summarized into the four functions mentioned above. In its application, the management functions are carried out in stages, beginning with the preparation of plans, organizing people into working groups (mobilization) and accompanied by supervision.Management is an effort to make use of available resources so that the optimal use of resources can be achieved as optimal as possible.

Then, for the understanding of Human Resources (HR) is merelypersonal or employees or also employees who work in an organizational environment. This simple understanding tends to have an impact on the management of human resources in an organizational environment that must be harmonious and can fulfill the nature, dignity and universal needs of these human beings[15]. Thus, Human Resource Management is the process of utilizing the help of others humanely, to provide the best contribution in achieving organizational goals. It is the ability to utilize and treat other people humanely so that it is integrated with other resources, in realizing a healthy or good organization and able to develop its existence according to changing environmental conditions.Also, Human Resource Management is an effort to realize an organization whose existence is needed by the community, through planning and actions to provide public services as well as implementing development for the welfare of the community. It focuses on improving the ability to carry out its work in a sustainable manner based on ethics and high social responsibility at work.

\section{B. Definition of Education Quality}

Quality has some elements[16]. Firstly, it covers the effort to meet or exceed customer expectations. Secondly, it involves products, services, people, processes and the environment. Thirdly, it is a condition that is always changing, so that it can be defined as a dynamic condition that is related to products, services, people, processes and the environment that meet and even exceed expectations.Quality is generally contained in the meaning of the degree of superiority of a product (work/effort) in the form of goods or

\footnotetext{
IJoASER, Volume 1, Issue 2, July 2018

DOI: 10.33648/ijoaser.v1i2.12

Copyright: STAI Al-Furqan Makassar, Indonesia

Content License: CC-BY-SA
} 
services, both tangible and intangible[17]. In the context of education which refers to the educational process and the results of education. The education process is said to be of quality contained in it are various inputs such as teaching materials (cognitive, affective and psychomotor), methodologies, school facilities, administrative support, infrastructure facilities, and other resources as well as the creation of a conducive atmosphere.The quality in the perspective of educational outcomes refers to the achievements achieved by the school in a certain period. The achievements achieved are usually in the form of academic and non-academic tests (sports, arts or skills). Even school performance can also be in the form of conditions that cannot be held such as an atmosphere of discipline, intimacy, kinship, mutual respect, and an atmosphere of cleanliness in the school environment.

Then according to the Ministry of National Education[18] that in general, quality is the overall picture and characteristics of goods or services that show their ability to satisfy the expected or implied needs. Moreover,precisely the quality in the context of education includes the quality of education input, process, and output. The word of education couldmerelybe interpreted as conscious guidance or leadership by the educator towards the physical and spiritual development of the educated towards the formation of the leading personality. Based on this limitation, education must contain at least five crucial elements, namely the first (guidance) business (activity) and consciously carried out; both educators, or mentors or; some are educated or educated; fourth necessary and purposeful guidance; the five businesses contained the tools used.Thus, the quality of education in the context of educational outcomes refers to the achievements achieved by the school in a certain period[19]. Achievements could bias in the form of academic and non-academic test results.

\section{METHOD}

\section{A. The design of the study}

This study uses the basis of the qualitativestudy, namely study intended to understand the phenomena experienced by study subjects to produce descriptive data in the form of words written or oral from people and observed behavior. This study is attempted to be fundamental, profound and process oriented. This qualitative research is suitable because it is natural by requiring its integrity. It is subject to obtain in-depth understanding and interpretation of the facts and relevant reality[20] The design of the study is descriptive qualitative, which is a form of study to describe existing phenomena, both natural phenomena and human-made phenomena. This phenomenon can be in the form of forms, activities, characteristics, changes, similarities, and differences between one phenomenon and another. This study aims to gather information about the status of an existing phenomenon, namely the state of symptoms according to what they were at the time the studywas conducted so that it was only disclosure of facts by analyzing data[21]. 


\section{B. The Data Source of the Study}

Primary data sources are all data obtained directly at the location of the study in the form of an interview. The informants were the head of the Madrasah, the head of the Administration, and several teaching staff. This studywas conducted at Madrasah Aliyah IMMIM Makassar, Indonesia.IMMIM is one of the Islamic educational institutions in high demand by the community.

\section{Method of collecting data}

The next stage is the collection and data collection method is a way to obtain goals, this first method is used after the researcher takes into account the progress regarding the objectives and situation of the research. This interview method is used to find out the relationship with data sources, through question and answer to get the information needed. This interview was conducted in depth (depth interview) regarding the management of human resource management at Madrasah Aliyah Modern Islamic Boarding School IMMIM Makassar focusing on the head of the madrasah and several teachers and employees.

\section{The Instrument of the Study}

Quality research can be seen from the results of research, while the quality of research results are very dependent on the instruments and the quality of data collection. Two main things influence the quality of research results, namely the quality of research instruments and the quality of data collection. An interview guide is a tool in the form of notes on questions used in collecting data.

\section{E. Data Analysis}

The overall data processing and analysis techniques used in the study are qualitative. The data are presented in a descriptive phenomenological way to understand the meaning of events and their relationships that give rise to the analysis. The process of data processing and analysis takes place simultaneously which is carried out simultaneously with the data collection process with the following stages:

1) Data Reduction. The reduction is an election activity, simplification, concentration of attention from the raw data that has been obtained. The data that has been obtained is then recorded carefully and in detail. Reducing data means summarizing, choosing the main things, focusing on essential things, looking for themes and patterns that are considered relevant and vital related to human resource management in the perspective of education quality. Thus the reduced data will provide a clearer picture and make it easier to carry out further data collection.

2) Data presentation. After the data is reduced, the next step is to present the data. The presentation of the data in this study was carried out in the form of brief descriptions, charts, relationships between categories, and the like. This data presentation is done to make it easier to understand what happened and plan the next activity. 
3) Conclusions and verification. Data that has been patterned, focused and arranged systematically in the form of the narrative through the method of data induction is concluded, so that the meaning of the data can be found in the form of interpretation and argumentation. Conclusions took if there are still deficiencies to add.

\section{IV.RESULTS AND DISCUSSION}

\section{A. Personality Competencies of Madrasah Aliyahprincipal of IMMIM Modern Islamic Boarding Schools.}

Referring to the Minister of National Education Regulation No. 13 of 2007, which the government considers that there is a need to determine a person's qualifications to be appointed as a school principal or madrasah. In addition to general and unique qualifications for holding positions as head of a school/madrasah, it is required to have several competencies, namely: personality, managerial, entrepreneurial, supervision, and social competencies.

This study describes the competence of the Madrasah principal as well as the teaching staff by focusing on personality competence. The competence summarizes the overall potential and talents and interests of office as educational leaders within the scope of leadership. Madrasah under the auspices of the Pesantren,which has a vision and mission that implies the achievement of educational goals to be achieved. This requires the Madrasah principal to have several advantages. The Madrasah principal had the authority and was obeyed by all his subordinates. These advantages, for example, are shown in the moral and moral strengths, high morale, intelligence, environmental sensitivity, tenacity, and high integrity. In line with the description of teacher 1 :

The Madrasah principal has high authority and professionalism, so it is proper and reasonable to be obeyed by his subordinates. His first advantage was in the field of morals and morals, high fighting spirit, the sharpness of intelligence, tenacity, and high integrity, sincerity in dedicating himself as an educator and Madrasah principal (Teacher 1)

In this regard, the principal of the modern IMMIM Islamic Boarding School is also an essential part of educators, staff,and learners. That is to act first before ordering, and not just to give examples, but to be an example of the subordinates and others. The accuracy of SholatJama'ah in the mosque at any time with students, teachers, and advisors. Then diligently perform SholatDuha' in the mosque. This action certainly drives the spirit of the subordinates always to act better.

Madrasah leaders do have exemplary leadership spirit. Starting from matters of discipline, the practice of worship and so on. For example, everything that is recommended to be carried out has been done beforehand (Teacher 2).

He is always active in all Islamic activities; his people are disciplined and diligent. He entered always teaching on time and never left his teaching hours except for fundamental interests related to a meeting called for Madrasah 
principal or other Madrasah interests. Also, he has a good character that is exemplary (Teacher 3).

The results of the interviews show that the personality of the Madrasah principal is a type of education leader that is exemplary, both regarding morality, discipline, authority,and practice of worship.Furthermore, regardingpolicymaking in madrasah, researchers observed that among the prominent personalities of the leadership of madrasa leaders, it was openness in all policies. The head of the madrasah always tries to involve the authorities in each decision making.

In this case, the head of the madrasa always holds meetings to determine a policy, because one decision will be stronger if based on deliberation with the authorities (Teacher 4).

The leadership of the madrasah chief is not leadership that can decide anything, because everything that is going to be run is always discussed together, sitting together to discuss it, so that an agreement is reached (Teacher 5).

Madrasah heads continuously update knowledge regardingeducational development in general, curriculum development, madrasah management strategies and others. Then organizing the education process must be responsive to the challenges of the era of globalization, and actively trace the development and advancement of communication and information technology.

Education challenges today and in the future, as far as we can feel the current tendency. That is how to conduct education that is responsive to the challenges of the era of globalization. The advancement of communication and information technology has made the whole world like a global village. Through the internet, television, print media and so on, everything can be spread throughout the world in a short time (Teacher 6).

From the results of the interview, it can be seen that the organizers of education must be responsive to technological developments so that this is the basis of the madrasa head of the modern pesantrenIMMIM continually improving themselves as madrasa leaders and their efforts to continuously improve human resources in the Madrasah environment.

Furthermore, regarding the leadership spirit, he has. First, its leadership can be categorized as democratic leadership, but it must be acknowledged that other leadership traits sometimes also arise. At least so that the writer can conclude from the results of the interview with the Head of Administration. That is said to be democratic because the Madrasah Head in carrying out his leadership wheel, and in issuing policies always ask for consideration to all parties involved.

The leadership of the madrasah chief is not leadership that can decide anything, because everything that is going to be run is always discussed together, sitting together to discuss it, so that an agreementis reached. As for the authoritarian nature of his leadership, sometimes it also appears (Teacher 4). 
The connection with the authoritarian nature of leadership is made to enforce the agreed discipline. This is by the explanation of the madrasah head.

This is done primarily to enforce a mutually agreed discipline if anyone violates the discipline there is no compromise (Teacher 6).

Second, identify itself as an agent of change and renewal. Head of MA IMMIM Modern Islamic Boarding School, since the beginning of his leadership,commits to make changes towards the better. This is indicated by the presence of new breakthroughs such as that required by all homeroom teachers to always gather their guardian children in order to increase learning interest and motivation, improve learning discipline, then the classroom atmosphere is immaculate and well organized and equipped with complete device, plus other equipment that will create a more comfortable learning atmosphere.

At the homeroom meeting forum a few days ago we were directed to meet as often as possible with the children of the guardian so that everything we needed to evaluate was explained. Likewise, the improvement in learning achievement of our students is discussed (Teacher 2).

Second, have a substantial nature. This trait also exists in the figure of a Madrasah Aliyah principal of the modern Islamic boarding school IMMIM. When there are guardians of students, who come to question their children's values that are not by what is expected, the Madrasah Aliyah principal with full self-confidence gives a clear explanation with friendly attitude.

When there are guardians of students who come to question their children's values that are not by what is expected, he calmly and confidently explains clearly but still accompanied by an attitude of hospitality. He is firm but also very friendly and appreciative of others (Teacher 7).

The results of observations and interviews illustrate that the personality of the head of the madrasa which tends to be democratic, participatory and independent has been able to mobilize all elements of madrasah optimally through efforts to develop education quality.

\section{B. Professional Competence and Academic Qualifications of Educators at MA \\ IMMIM Modern Islamic Boarding Schools}

Referring to the Standards of Educators and Education Personnel based on the Government Regulation of the Republic of Indonesia National Education Standards. That educator must have academic qualifications and competencies as learning agents. Likewise, the educators at MA Modern Islamic Boarding School IMMIM Makassar have minimum undergraduate academic qualifications, and some are masters. The achievement of the minimum standard of formal education is a good enough capital for educators in carrying out their teacher training with professionals. Suitability between scientific background and teaching assignments also shows good levels.

This shows that it has fulfilled the professional element, namely specialization in its field because specific scientific mastery by its field must 
fully support professional work. For this reason, the madrasa in the management of the MA Modern Islamic Boarding School IMMIM has assigned educators to teach according to their science.

Educators at MA IMMIM Makassar Modern Pesantren have been equipped with Islamic knowledge and insights; this can be known by their success in selecting recruitment of educators. The maturity of this science shows their maturity. It is the responsibility of an educator in carrying out duties as a teacher on the mastery of the material in the field of study and the ability to manage learning programs.

Mastery of material in the field of study and this is the basic foundation for teaching skills. Then related to the management of the learning program which includes formulating competency standards and basic competencies, formulating syllabi, learning objectives, ability to use teaching methods / models, the ability to arrange the steps of learning activities, the ability to know the potential of students, and the ability to plan and implement remedial teaching. Now that we are applying the 2013 curriculum, this is our old curriculum updated with the reference of the $k 13$ code (Teacher 8 )

The findings show that the educator is responsible to the head of the madrasah and has the task of carrying out the teaching and learning process effectively and efficiently. The results of these observations are by the explanation by Teacher 2, the teacher of fiqh subjects,

According to him that:

The planning of our learning equipment was arranged before the new school year began, then submitted to the head of the madrasa for review. Then to be more effective and to streamline the learning process educators insert variations of learning strategies, and always improve learning media so that students are not monotonous and not bored (Teacher 2).

Furthermore, the explanation by Teacher 7:

Our duties as educators that we must fulfill are: Creating teaching programs, namely by reviewing subject matter, annual / semester programs, unit learning programs, teaching plan programs, weekly teacher programs, student activity sheets. We describe these components in the learning tools that we specifically compile. Then other tasks such as: Carrying out learning assessment activities, daily tests, semester / yearly, analyzing the results of the students' daily tests, preparing improvement and enrichment programs, filling in the list of student grades, making necessary learning tools, making notes about the progress of each student's learning outcomes, examine the student attendance list before starting the lesson and then we compile it in another sheet (Teacher 7).

As for Teacher 5 exposure, it is related to an educator's understanding of the characteristics of students and another potential that must be possessed.

Usually, a person must have insight into educational research. For example research class action. Furthermore, understanding the characteristics of students because in addition to teaching also educates and educates students, also required to have a deeper understanding of the characteristics and development of students, then adjust the material to be taught according to the characteristics

IJoASER, Volume 1, Issue 2, July 2018

DOI: 10.33648/ijoaser.v1i2.12

Copyright: STAI Al-Furqan Makassar, Indonesia

Content License: CC-BY-SA 
of students. Another thing that is not less important is that it is always important to understand the curriculum and its development so that in carrying out teaching tasks it is always planned and structured, and can use the time appropriately (Teacher 5).

The results of interviews with various sources of teaching staff can be concluded that educators have fulfilled the requirements that must be possessed by teachers in professional competence.These findings are reinforced by the explanation of the head of the modern Islamic boarding school Islamic boarding school IMMIM Makassar.

In general, teachers in this madrasah can be categorized as having met the competency standards that must be possessed by a teacher or educator, as well as professional competence. Although regarding loyalty the educators will still be boosted (Teacher 6).

The conclusions from the observations and interviews indicate that the professional qualifications and competencies of the Madrasah Aliyah Modern Islamic Boarding School students of IMMIM Makassar are categorized as good. MA teaching staff, Modern Islamic boarding school IMMIM, has the competencies required to carry out educational and teaching tasks in the Islamic boarding schools. With basic skills in knowledge about learning and behavior, as well as his expertise in the field of study he develops, the right attitude about the learning environment and having the skills in teaching techniques plus mastery of learning material widely and deeply so as to guide students to meet the competency standards set in National Education Standards.

\section{CONCLUSION}

Human resources at Madrasah Aliyah of IMMIM Modern Islamic Boarding School Makassar can be categorized as good, the Head of the madrasah, Educators, leads human resources, and the administrationhas the competence that must be fulfilled as educators and education staff so that they can carry out their duties well. First, the vision and mission that has signaled the objectives of the MA modern Islamic boarding school's education journey affect all madrasa stakeholders always to strive to do the work of 'achievement' in each of their work activities. Second, the leadership of madrasa leaders who are democratic and participatory has been able to mobilize all elements of madrasah optimally through efforts to develop education quality. Thirdly, human resources personnel who continuously experience capacity building can assist madrasah management in the process of developing education quality.

The results of this study could be one of the information and references on the need for a review of the activities of human resource management at Madrasah Aliyah of IMMIM Modern Islamic Boarding School Makassar to improve quality. Especially for the quality from the perspective of internal customers consisting of teachers and employees as "motorbikes" all madrasa activities.This is important because educators/teachers and education staff/employees are not just factors of production but also assets that need attention. Therefore, teachers and employees comprise whole human beings 
who have a variety of complex needs. For educators/teachers and education staff/employees should always strive to improve the ability and professionalism in carrying out their duties through a variety of independent efforts. This study could be followed up with a broader model where more objects of the study could be usedand more parameters or indicators can be used to reveal the actual reality.

\section{REFERENCES}

[1] M. T. Hasan and A. N. Anies, Islam dan masalah sumber daya manusia. Jakarta: Lantabora Press, 2005.

[2] A. Azra, Pendidikan Islam: tradisi dan modernisasi menuju milenium baru. Logos Wacana Ilmu, 1999.

[3] E. N. Rachmawati, "Paradigma Baru Manajemen Sumber Daya Manusia Sebagai Basis Meraih Keunggulan Kompetitif," Yogyakarta, Ekonisia, 2004.

[4] M. Sirozi, Agenda strategis pendidikan Islam. AK Group, 2004.

[5] A. Cahayani, "Strategi dan Kebijakan Manajemen Sumber Daya Manusia," Jakarta Indeks, 2005.

[6] A. M. Fadjar, Madrasah dan tantangan Modernitas. Diterbitkan atas kerja sama Yasmin [dan] Penerbit Mizan, 1998.

[7] M. Qomar, Manajemen Pendidikan Islam: Strategi Baru Pengelolaan Lembaga Pendidikan Islam. Erlangga, 2007.

[8] R. I. Departemen Agama, "Al Qur'an dan Terjemahannya, 2008," Jakarta CV Pustaka Agung Harapan.

[9] H. Soewarno, "Pengantar Studi Ilmu Administrasi dan Manajemen," Jakarta, Gunung Agung, 1994.

[10] G. R. Terry, Principles of Management: Irwin Series in Industrial Engineering and Management. Literary Licensing, LLC, 2012.

[11] H. Koontz and C. O'Donnell, Principles of management: an analysis of managerial functions. McGraw-Hill, 1972.

[12] A. F. Sikula, Personnel administration and human resources management. John Wiley \& Sons, 1975.

[13] O. Hamalik, Manajemen pengembangan kurikulum. Sekolah Pascasarjana Universitas Pendidikan Indonesia dengan PT Remaja Rosdakarya, 2006.

[14] J. A. F. Stoner, "Risky and cautious shifts in group decisions: The influence of widely held values," J. Exp. Soc. Psychol., vol. 4, no. 4, pp. 442-459, 1968.

[15] H. Nawawi, Manajemen Strategik organisasi non profit bidang pemerintahan dengan ilustrasi di bidang pendidikan. Gadjah Mada University Press, 2000.

[16] L. J. Porter and A. J. Parker, "Total quality management- the critical success factors," Total Qual. Manag., vol. 4, no. 1, pp. 13-22, Jan. 1993.

[17] B. Suryosubroto, Manajemen pendidikan di sekolah. Rineka Cipta, 2004.

[18] Depdiknas, "Manajemen Berbasis Sekolah.” Dirjen Dikdasmen Dir.PLP, Jakarta, 2005.

[19] A. Nata, Paradigma pendidikan Islam: kapita selekta pendidikan Islam. Gramedia Widiasarana Indonesia bekerjasama dengan IAIN Syarif Hidayatullah, 2001.

[20] L. J. Moleong, "Metodologi penelitian," Bandung PT. Remaja Rosda Karya, 1999.

[21] A. Suharsimi, "Manajemen penelitian," Jakarta: Rineka Cipta, 2005.

[22] P. R. Hinton, I. McMurray, and C. Brownlow, SPSS explained. Routledge, 2014.

[23] N. M. S. Wedarini, "Pengaruh Kualitas Produk Terhadap Kepuasan dan Loyalitas Pelanggan TELKOM FLEXI," E-Jurnal Manaj. Univ. Udayana; Vol 2 No 5, May 2013.

[24] M. Musriha, "Pengaruh Servicecape dan Kualitas Komunikasi Karyawan terhadap Loyalitas Nasabah melalui Kepuasan Nasabah Bank Mandiri di Surabaya," EKUITAS (Jurnal Ekon. dan Keuangan), vol. 15, no. 2, pp. 247-268, 2017.

[25] A. Novita, "Pengaruh Kualitas Produk, Kualitas Pelayanan, dan Komunikasi Interpersonal terhadap Loyalitas Nasabah pada PT. Bank Sulutgo Cabang Utama Manado," J. Berk. Ilm. Efisiensi, vol. 16, no. 1, 2016. 
